\title{
PENGEMBANGAN MODUL PEMBELAJARAN BIOLOGI BERBASIS READING, QUESTIONING, AND ANSWERING (RQA) MATERI VIRUS KELAS X
}

\author{
Khairatul Ummah, Mucharommah Sartika Ami, Ospa Pea Yuanita Meishanti \\ Prodi Pendidikan Biologi, FIP, Universitas K.H. A. Wahab Hasbullah; Jombang \\ e-mail: ${ }^{* 1}$ khairatulumma22@gmail.com
}

\begin{abstract}
Abstrak
Penelitian ini bertujuan untuk: (1) mendeskripsikan kelayakan modul pembelajaran biologi berbasis Reading, Questioning, and Answering (RQA) materi virus berdasarkan nilai hasil validasi oleh ahli materi; (2) mendeskripsikan kelayakan modul pembelajaran biologi berbasis Reading, Questioning, and Answering (RQA) materi virus berdasarkan nilai hasil validasi oleh ahli media pembelajaran; dan (3) mendeskripsikan respon peserta didik terhadap keterbacaan modul pembelajaran biologi berbasis Reading, Questioning, and Answering (RQA) materi virus yang dikembangkan. Penelitian ini merupakan penelitian pengembangan yang menggunakan model pengembangan ADDIE. Prosedur penelitian mengacu pada tahapan dalam model pengembangan ADDIE, yaitu: Analysis, Design, Develop, Implement, dan Evaluate. Tahap analysis adalah kegiatan analisis kebutuhan pengembangan modul berbasis RQA materi virus. Tahap design dilakukan untuk menyusun rancangan modul yang dikembangkan, meliputi speisifikasi teknis dan substantif. Tahap develop merupakan pembuatan modul dan validasi ahli. Tahap implement merupakan tahap uji coba kelompok kecil untuk mengetahui keterbacaan peserta didik. Tahap terakhir (evaluate) merupakan kegiatan evaluasi hasil seluruh tahap yang telah dilakukan. Teknik pengumpulan data yang digunakan adalah wawancara dan angket. Instrumen yang digunakan antara lain: pedoman wawancara, angket analisis kebutuhan peserta didik, lembar validasi ahli materi, lembar validasi ahli media pembelajaran, dan angket respon peserta didik. Validator ahli materi dan ahli media pembelajaran yang melakukan validasi masing-masing satu orang yang memiliki keahlian di bidangnya. Jumlah responden yang memberikan respon keterbacaan modul yang dikembangkan sebanyak 10 orang. Data yang diperoleh dianalisis secara deskriptif. Hasil penelitian ini menunjukkan bahwa modul pembelajaran biologi berbasis RQA materi virus dinyatakan sangat layak. Hasil kelayakan ini diperoleh dari hasil validasi ahli materi dengan persentase rata-rata 92.18\% (kriteria sangat layak), hasil validasi ahli media pembelajaran dengan persentase rata-rata 93,42\% (kriteria sangat layak), dan persentase rata-rata respon peserta didik sebesar 93\% (kriteria sangat baik).
\end{abstract}

Kata kunci-modul, model RQA, materi virus.

\section{PENDAHULUAN}

Mata pelajaran biologi mempelajari tentang makhluk hidup, mulai dari makhluk hidup tingkat rendah hingga makhluk hidup tingkat tinggi. Materi-materi dalam mata pelajaran biologi terkadang memuat konsep yang kompleks dan banyak istilah dalam Bahasa Latin yang sulit dipahami. Hasil analisis kebutuhan yang dilakukan peneliti terhadap peserta didik menunjukkan bahwa hal tersebut termasuk faktor yang mempengaruhi motivasi belajar peserta didik. Salah satu materi dalam mata pelajaran biologi yang dianggap sulit adalah materi virus. Media pembelajaran yang dianggap kurang menarik oleh peserta didik semakin menurunkan minat baca dan motivasi belajarnya. Berdasarkan hasil observasi dan wawancara yang dilakukan kepada guru mata pelajaran biologi pada bulan Desember 2019 di Madrasah Aliyah (MA) Bahrul 'Ulum Tambakberas Jombang menunjukkan bahwa reaksi peserta didik terhadap proses pembelajaran biologi kurang aktif. Materi virus dianggap begitu asing bagi peserta didik daripada materi lainnya yang sudah dipelajari sebelumnya. Minat baca peserta didik terhadap materi pelajaran juga cukup rendah, media pembelajaran yang digunakan adalah Lembar Kerja Siswa (LKS) dan jumlah peserta didik yang memenuhi Kriteria Ketuntasan Minimal (KKM) hanya 50\%. Permasalahan tersebut perlu diatasi dengan inovasi yang mampu memotivasi peserta didik dalam melaksanakan berbagai aktivitas belajar, meningkatkan pemahaman, minat baca peserta didik dan partisipasi aktif peserta didik dalam kegiatan pembelajaran.

Salah satu solusi yang dapat dilakukan adalah mengembangkan modul pembelajaran biologi berbasis Reading, Questioning, and Answering (RQA) sebagai media pembelajaran materi virus. Modul merupakan bahan ajar yang disusun secara sistematis dengan bahasa yang mudah dipahami oleh peserta didik, sesuai usia dan tingkat pengetahuan mereka agar mereka dapat belajar secara mandiri dengan ada atau tidaknya bimbingan dari pendidik [1]. Kelebihan dari modul yaitu dapat digunakan secara mandiri dengan adanya 
umpan balik, mengatasi keterbatasan ruang dan waktu, peserta didik dapat belajar sesuai kemampuannya, dan dapat mengukur atau mengevaluasi hasil belajarnya sendiri. Kekurangan modul biasanya terletak pada strategi pembelajaran yang digunakan sebagai dasar penyusunannya yang cenderung konvensional dan monoton, sehingga menyebabkan peserta didik tidak disiplin dalam menggunakan modul [2].

Model pembelajaran $R Q A$ ini dapat mendorong peserta didik untuk membaca, memahami serta menemukan bagian-bagian materi yang penting atau sangat penting. Peserta didik juga dituntut untuk mampu membuat pertanyaan dan menjawabnya. Model pembelajaran $R Q A$ juga berpotensi membuat daya berpikir peserta didik meningkat [3]. Kelebihan model RQA yaitu mampu menjadikan peserta didik lebih siap dalam mengikuti pembelajaran dengan cara membaca materi pelajaran terlebih dahulu, sehingga peserta didik akan lebih mudah dalam mengikuti pelajaran dan juga dalam memahami materi yang akan diajarkan, menjadikan peserta didik aktif secara individu dan dapat meningkatkan kemampuan berpikir peserta didik. Kekurangan model $R Q A$ yaitu selama pembelajaran peserta didik hanya didorong untuk mempersiapkan diri secara individu, sehingga kemampuan peserta didik bekerja sama dalam kelompok menjadi rendah [4]. Kekurangan ini dapat diatasi dengan kegiatan diskusi kelas di tahap answering sehingga peserta didik tetap dapat melatih keterampilan sosialnya. Tujuan penelitian ini antara lain: (a) mendeskripsikan kelayakan modul pembelajaran biologi berbasis Reading, Questioning, and Answering (RQA) materi virus berdasarkan hasil validasi ahli materi; (b) mendeskripsikan kelayakan modul pembelajaran biologi berbasis Reading, Questioning, and Answering $(R Q A)$ materi virus berdasarkan hasil validasi ahli media pembelajaran; dan (c) mendeskripsikan respon peserta didik terhadap keterbacaan modul pembelajaran biologi berbasis Reading, Questioning, and Answering (RQA) materi virus yang dikembangkan. Hasil dari penelitian ini diharapkan dapat meningkatkan minat baca, meningkatkan motivasi belajar, pemahaman, keaktifan dalam kegiatan pembelajaran di kelas, dan dapat meningkatkan hasil belajar peserta didik.

\section{METODE PENELITIAN}

Penelitian ini dilaksanakan selama bulan Oktober 2020 secara daring. Penelitian ini menggunakan model pengembangan ADDIE yang memiliki 5 tahapan yaitu: Analysis, Design, Development, Implemention, Evaluation [5]. Pemilihan model pengembangan ADDIE ini didasarkan pada tahapan-tahapan yang mudah dipelajari, sederhana, efektif dan efisien. Teknik pengumpulan data yang digunakan adalah wawancara dan angket. Instrumen yang digunakan antara lain: pedoman wawancara untuk guru, angket analisis kebutuhan untuk peserta didik, lembar validasi ahli materi, lembar validasi ahli media pembelajaran dan angket respon peserta didik. Pedoman wawancara untuk guru dan angket analisis kebutuhan untuk peserta didik digunakan sebagai instrumen pengumpulan data pada tahap analisis (analysis). Tahap kedua dari model ADDIE adalah design, yaitu perancangan spesifikasi modul pembelajaran yang dikembangkan. Tahap ketiga adalah develop, yaitu pengembangan modul berdasarkan rancangan yang telah ditentukan dari tahap sebelumnya. Pada tahap ini dilakukan pula validasi ahli. Ada dua orang validator yang melakukan penilaian kelayakan modul pembelajaran yang dikembangkan, yaitu ahli materi dan ahli media pembelajaran. Instrumen yang digunakan dalam kegiatan validasi adalah lembar validasi ahli materi dan lembar validasi ahli media pembelajaran.

Modul yang telah divalidasi selanjutnya direvisi berdasarkan saran dan masukan dari ahli materi dan ahli media pembelajaran. Modul yang telah direvisi, selanjutnya diuji coba dalam kelompok kecil yang terdiri dari 10 orang peserta didik kelas $X$. Kegiatan uji coba ini merupakan tahap implement, yang bertujuan untuk mengetahui keterbacaan modul pembelajaran yang dikembangkan. Data yang diperoleh dari hasil validasi dan uji coba pada peserta didik berupa skor dan saran. Data skor dihitung menggunakan rumus berikut:

Persentase kelayakan $(\%)=\frac{\text { jumlah skor yang diperoleh }}{\text { skor maksimal }} \times 100 \%$

Persentase yang diperoleh kemudian diinterpretasi menggunakan kriteria interpretasi skor kelayakan dan respon peserta didik [6] yang ditunjukkan pada Tabel 1.

Tabel 1 Kriteria Interpretasi Skor Kelayakan dan Respon Peserta Didik

\begin{tabular}{ccc}
\hline Persentase Rata-rata & Kriteria Kelayakan & Kriteria Respon Peserta Didik \\
\hline $0-20$ & Tidak Layak & Tidak Baik \\
\hline $21-40$ & Kurang Layak & Kurang Baik \\
\hline $41-60$ & Cukup Layak & Cukup Baik \\
\hline $61-80$ & Layak & Baik \\
\hline $81-100$ & Sangat Layak & Sangat Baik \\
\hline
\end{tabular}


Jurnal Biologi dan Pembelajarannya, Vol 5 No 2, April 2021. Pp: 19-25

e-ISSN: $2406-8659$

\section{HASIL DAN PEMBAHASAN}

Data yang diperoleh melalui penelitian pengembangan ini antara lain: data analisis kebutuhan, data hasil validasi ahli materi dan ahli media pembelajaran, serta data respon peserta didik. Hasil analisis kebutuhan menunjukkan bahwa peserta didik membutuhkan media pembelajaran yang menarik dan mampu meningkatkan minat baca untuk membantunya mempelajari materi virus yang dianggap sulit. Guru belum pernah menggunakan modul berbasis RQA sebagai media pembelajaran biologi, termasuk pada materi virus. Berdasarkan hasil analisis kebutuhan tersebut, maka dikembangkan modul pembelajaran berbasis Reading, Questioning and Answering (RQA) materi virus kelas X. Hasil validasi ahli materi (Tabel 2) dan hasil validasi ahli media pembelajaran (Tabel 3) digunakan sebagai penentu kelayakan modul yang dikembangkan.

Tabel 2 Data Hasil Validasi Ahli Materi

\begin{tabular}{|c|c|c|c|c|c|c|}
\hline \multirow{2}{*}{ Aspek } & \multirow{2}{*}{ No } & \multirow{2}{*}{ Kriteria } & \multicolumn{3}{|c|}{ Skor } & \multirow{2}{*}{ Keterangan } \\
\hline & & & $\mathbf{x}$ & $\mathbf{X i}$ & $\%$ & \\
\hline \multirow[t]{4}{*}{ Isi } & 1 & $\begin{array}{l}\text { Kesesuaian materi dengan } \\
\text { Kompetensi Dasar, } 3.4 \\
\text { "menganalisis struktur, replikasi } \\
\text { dan peranan virus dalam } \\
\text { kehidupan" dan } 4.4 \text { "melakukan } \\
\text { kampanye tentang bahaya virus } \\
\text { dalam kehidupan terutama } \\
\text { bahaya AIDS berdasarkan tingkat } \\
\text { virulensinya" }\end{array}$ & 4 & 4 & 100 & Sangat Layak \\
\hline & 2 & $\begin{array}{l}\text { Kelengkapan materi, keluasan } \\
\text { materi dan kedalaman materi } \\
\text { yang disajikan }\end{array}$ & 3 & 4 & 80 & Layak \\
\hline & 3 & $\begin{array}{l}\text { Kemutakhiran dan kontekstualitas } \\
\text { materi yang disajikan }\end{array}$ & 4 & 4 & 100 & Sangat Layak \\
\hline & 4 & Akurasi materi yang disajikan & 4 & 4 & 100 & Sangat Layak \\
\hline \multirow{7}{*}{ Penyajian } & 5 & Konsistensi sistematika sajian & 4 & 4 & 100 & Sangat Layak \\
\hline & 6 & $\begin{array}{l}\text { Kesesuaian dan ketepatan ilustrasi } \\
\text { dengan materi yang disajikan }\end{array}$ & 3 & 4 & 80 & Layak \\
\hline & 7 & Peta konsep & 4 & 4 & 100 & Sangat Layak \\
\hline & 8 & Rangkuman & 4 & 4 & 100 & Sangat Layak \\
\hline & 9 & Soal latihan dalam akhir bab & 4 & 4 & 100 & Sangat Layak \\
\hline & 10 & Kunci jawaban pada akhir buku & 4 & 4 & 100 & Sangat Layak \\
\hline & 11 & $\begin{array}{l}\text { Rujukan untuk tabel, gambar dan } \\
\text { lampiran }\end{array}$ & 4 & 4 & 100 & Sangat Layak \\
\hline \multirow{7}{*}{ Bahasa } & 12 & $\begin{array}{l}\text { Kesesuaian dan keterbacaan } \\
\text { bahasa yang digunakan }\end{array}$ & 3 & 4 & 80 & Layak \\
\hline & 13 & $\begin{array}{l}\text { Kelugasan materi yang meliputi } \\
\text { ketepatan struktur kalimat dan } \\
\text { kebakuan istilah yang digunakan }\end{array}$ & 3 & 4 & 80 & Layak \\
\hline & 14 & $\begin{array}{l}\text { Keruntutan dan keterkaitan isi } \\
\text { antar bab/sub bab/kalimat/alinea }\end{array}$ & 3 & 4 & 80 & Layak \\
\hline & 15 & $\begin{array}{l}\text { Kesesuaian dengan kaidah bahasa } \\
\text { Indonesia, sesuai Ejaan Yang } \\
\text { Disempurnakan (EYD) }\end{array}$ & 4 & 4 & 100 & Sangat Layak \\
\hline & 16 & $\begin{array}{l}\text { Kebenaran dan kejelasan } \\
\text { penggunaan istilah dan } \\
\text { simbol/lambang }\end{array}$ & 4 & 4 & 100 & Sangat Layak \\
\hline & & Jumlah & 59 & 64 & & \\
\hline & & Rata-rata & & & & gat Layak \\
\hline
\end{tabular}

\section{Keterangan:}

$\mathrm{X}=$ Skor dari Ahli Materi

$\mathrm{Xi}=$ Skor Maksimal

$\% \quad=$ Persentase Skor Tiap Butir Pertanyaan 
Persentase rata-rata hasil penilaian ahli materi terhadap modul pembelajaran yang dikembangkan adalah 92,18\% dengan kriteria sangat layak. Ada 16 aspek yang menjadi penilaian ahli materi, sebanyak 11 aspek mendapatkan skor 4 dan lima aspek mendapatkan skor 3. Validator ahli materi memberikan skor 3 untuk aspek kelengkapan, keluasan, dan kedalaman materi yang disajikan karena sajian materi dalam modul dinilai kurang lengkap dan luas. Validator menyarankan untuk menambahkan pembahasan tentang Covid-19. Peneliti sudah menambahkan pembahasan tentang Covid-19 pada halaman 1 pada modul, hal ini bertujuan untuk keluasan materi virus. Materi pada suatu bahan ajar, misalnya modul, dapat dilengkapi dengan informasi-informasi yang berkaitan dengan situasi terkini dalam kehidupan peserta didik [7]. Kesesuaian dan ketepatan ilustrasi dengan materi yang disajikan juga memperoleh skor 3 karena materi yang disajikan pada modul kurang sesuai. Peneliti sudah memperbaiki ilustrasi yang sesuai dengan penjelasan dalam materi. Ilustrasi yang tepat akan mendukung pemahaman materi pada pembaca [8]. Kesesuaian dan keterbacaan bahasa yang digunakan memperoleh skor 3 karena validator menilai bahwa bahasa yang disajikan pada modul kurang komunikatif sehingga pembaca kurang memahaminya. Peneliti memperbaiki bahasa yang digunakan dalam modul menjadi bahasa yang komunikatif sehingga dapat dipahami. Bahasa yang komunikatif dapat membantu pemahaman pada materi yang disajikan [9]. Kelugasan materi yang meliputi ketepatan struktur kalimat dan kebakuan istilah yang digunakan juga memperoleh skor 3 karena kalimat atau istilah yang digunakan dalam modul kurang tepat sehingga pemahaman pembaca kurang. Peneliti memperbaiki tulisan istilah yang masih belum benar agar dapat dipahami. Penggunaan istilah terkadang membuat peserta didik bingung karena tidak mengerti arti atau maksud istilah tersebut, sehingga ketepatan istilah dalam bacaan sangat perlu diperhatikan [10]. Aspek penilaian kelima yang memperoleh skor 3 adalah keruntutan dan keterkaitan isi antar bab, hal ini karena materi dalam modul kurang terkait satu sama lain. Peneliti memperbaiki dari awal bab sampai akhir, hal ini bertujuan agar keruntutan dan kesesuaian isi antar bab sesuai. Penyajian materi biasa dilihat dari keruntutan materi, misalnya dari umum ke khusus. Kejelasan tentang apa yang akan dicapai dalam pembelajaran harus termuat secara runtut dalam buku ajar misalnya modul untuk membangkitkan motivasi belajar [11].

Tabel 3 Data Hasil Validasi Ahli Media

\begin{tabular}{|c|c|c|c|c|c|c|}
\hline \multirow{2}{*}{ Aspek } & \multirow{2}{*}{ No } & \multirow{2}{*}{ Kriteria } & \multicolumn{3}{|c|}{ Skor } & \multirow{2}{*}{ Keterangan } \\
\hline & & & $\mathrm{x}$ & $\mathbf{X i}$ & $\%$ & \\
\hline \multirow{8}{*}{ Penyajian } & 1 & $\begin{array}{l}\text { Kesesuaian teknik penyajian yaitu } \\
\text { konsistensi sistematika sajian dalam } \\
\text { bab, kelogisan penyajian, keruntutan } \\
\text { penyajian, koherensi, dan } \\
\text { keseimbangan substansi antar bab/sub } \\
\text { bab }\end{array}$ & 3 & 4 & 100 & Sangat Layak \\
\hline & 2 & Soal latihan di setiap bab & 4 & 4 & 80 & Layak \\
\hline & 3 & Peta konsep di setiap awal bab & 4 & 4 & 100 & Sangat Layak \\
\hline & 4 & Rangkuman di setiap akhir bab & 4 & 4 & 100 & Sangat Layak \\
\hline & 5 & Soal latihan dalam akhir bab & 4 & 4 & 100 & Sangat Layak \\
\hline & 6 & Kunci jawaban pada akhir buku & 4 & 4 & 100 & Sangat Layak \\
\hline & 7 & $\begin{array}{l}\text { Rujukan untuk tabel, gambar dan } \\
\text { lampiran }\end{array}$ & 4 & 4 & 100 & Sangat Layak \\
\hline & 8 & $\begin{array}{l}\text { kelengkapan penyajian merupakan } \\
\text { urutan dalam penulisan modul yang } \\
\text { terdiri atas, pendahuluan, daftar isi, } \\
\text { glosarium, daftar pustaka, dan indeks }\end{array}$ & 4 & 4 & 100 & Sangat Layak \\
\hline \multirow{4}{*}{ Bahasa } & 9 & $\begin{array}{l}\text { Kesesuaian dan keterbacaan bahasa } \\
\text { yang digunakan }\end{array}$ & 3 & 4 & 80 & Layak \\
\hline & 10 & $\begin{array}{l}\text { Kelugasan materi yang meliputi } \\
\text { ketepatan struktur kalimat dan } \\
\text { kebakuan istilah yang digunakan }\end{array}$ & 3 & 4 & 80 & Layak \\
\hline & 11 & $\begin{array}{l}\text { Keruntutan dan keterkaitan isi antar } \\
\text { bab/sub bab/kalimat/alinea }\end{array}$ & 4 & 4 & 100 & Sangat Layak \\
\hline & 12 & $\begin{array}{l}\text { kesesuaian dengan kaidah bahasa } \\
\text { Indonesia, sesuai Ejaan Yang } \\
\text { Disempurnakan (EYD) }\end{array}$ & 4 & 4 & 100 & Sangat Layak \\
\hline
\end{tabular}


Jurnal Biologi dan Pembelajarannya, Vol 5 No 2, April 2021. Pp: 19-25

e-ISSN: $2406-8659$

\begin{tabular}{|c|c|c|c|c|c|c|c|}
\hline \multirow{2}{*}{\multicolumn{2}{|c|}{ Aspek }} & \multirow{2}{*}{ No } & \multirow{2}{*}{ Kriteria } & \multicolumn{3}{|c|}{ Skor } & \multirow{2}{*}{ Keterangan } \\
\hline & & & & $\mathbf{x}$ & $\mathbf{X i}$ & $\%$ & \\
\hline & & 13 & $\begin{array}{l}\text { Kebenaran dan kejelasan penggunaan } \\
\text { istilah dan simbol/lambang }\end{array}$ & 3 & 4 & 80 & Layak \\
\hline \multirow{6}{*}{\multicolumn{2}{|c|}{ Kegrafikan }} & 14 & $\begin{array}{l}\text { Ukuran modul dengan standar ISO } \\
\text { yaitu A4 }(210 \times 297 \mathrm{~mm})\end{array}$ & 4 & 4 & 80 & Layak \\
\hline & & 15 & $\begin{array}{l}\text { Desain kulit, belakang dan punggung } \\
\text { memiliki kesatuan }\end{array}$ & 4 & 4 & 80 & Layak \\
\hline & & 16 & $\begin{array}{l}\text { Ukuran unsur tata letak proporsional } \\
\text { dengan ukuran buku }\end{array}$ & 4 & 4 & 80 & Layak \\
\hline & & 17 & $\begin{array}{l}\text { Warna unsur tata letak harmonis dan } \\
\text { memperjelas materi fungsi, serta } \\
\text { warna yang memiliki kontras yang baik }\end{array}$ & 3 & 4 & 100 & Sangat Layak \\
\hline & & 18 & $\begin{array}{l}\text { Penempatan unsur tata letak konsisten } \\
\text { berdasarkan pola }\end{array}$ & 4 & 4 & 100 & Sangat Layak \\
\hline & & 19 & $\begin{array}{l}\text { Pemisahan antar paragraf jelas, serta } \\
\text { kesesuaian spasi teks dan ilustrasi }\end{array}$ & 4 & 4 & 100 & Sangat Layak \\
\hline & & & Jumlah & 71 & 76 & & \\
\hline & & & Rata-rata & & $42 \%$ & & $\begin{array}{l}\text { Sangat } \\
\text { Layak }\end{array}$ \\
\hline \multicolumn{8}{|c|}{ Keterangan: } \\
\hline \multicolumn{8}{|c|}{$\mathrm{X}=$ Skor dari Ahli Media } \\
\hline \multicolumn{8}{|c|}{$\mathrm{Xi} \quad=$ Skor Maksimal } \\
\hline \multicolumn{8}{|c|}{$\%=$ = Persentase Skor Tiap Butir Pertanyaan } \\
\hline
\end{tabular}

Persentase rata-rata hasil penilaian ahli media pembelajaran terhadap modul pembelajaran yang dikembangkan sebesar 93,42\% dengan kriteria sangat layak. Ada 19 aspek penilaian, sebanyak 14 mendapatkan skor 4 dan lima aspek mendapatkan skor 3. Validator memberikan skor 3 untuk aspek kesesuaian teknik penyajian karena keruntutan penyajian dalam modul masih ada yang tidak runtut. Peneliti memperbaiki dari awal bab sampai akhir bab dan menambahkan peranan virus dalam rangkuman pada modul. Penyajian materi biasa dilihat dari keruntutan materi, misalnya dari umum ke khusus [12] Kejelasan tentang apa yang akan dicapai dalam pembelajaran harus termuat secara runtut dalam buku ajar misalnya modul untuk membangkitkan motivasi belajar. Kesesuaian dan keterbacaan bahasa yang digunakan karena bahasa yang disajikan kurang dapat dipahami. Peneliti memperbaiki bahasa yang digunakan menjadi bahasa yang dapat dipahami oleh pembaca. Keterbacaan merupakan ukuran yang dilihat dari tingkat kesulitan atau kemudahan teks untuk dapat dipahami oleh pembaca atau peserta didik [13]. Kelugasan materi yang meliputi ketepatan struktur kalimat dan kebakuan istilah yang digunakan memperoleh skor 3 karena kalimat yang digunakan berbelit-belit sehingga kalimat tidak mudah dipahami. Peneliti memperbaiki kalimat dan istilah yang digunakan dalam modul sehingga menjadi kalimat yang tidak membingungkan peserta didik dan yang mudah dipahami. Penggunaan istilah terkadang membuat peserta didik bingung karena tidak mengerti arti atau maksud istilah tersebut. Penilaian validator pada kriteria kebenaran dan kejelasan penggunaan istilah dan simbol/lambang memperoleh skor 3 karena ada beberapa istilah asing atau nama ilmiah yang belum dicetak miring. Peneliti memperbaiki cara penulisan nama ilmiah dengan baik, sehingga peserta didik juga dapat mengetahui cara penulisan nama ilmiah. Penulisan istilah atau nama ilmiah yang benar ialah dengan cara dicetak miring atau digaris bawahi [14]. Penilaian kriteria terakhir yang memperoleh skor 3 ialah warna unsur tata letak harmonis dan memperjelas materi fungsi, serta warna yang memiliki kontras yang baik. Validator menilai bahwa penataan unsur tata letak pada cover muka, punggung dan belakang sudah memiliki kesatuan, namun pada bagian sampul atau cover hanya diberi gambar virus bakteriofag, sehingga validator menyarankan untuk menambahkan gambar bentuk virus yang lainnya, agar menarik dan tidak menimbulkan presepsi bahwa bentuk virus bukan hanya bakteriofag. Peneliti menambahkan beberapa gambar bentuk virus yang lainnya agar peserta didik tidak berpikir bahwa bentuk virus hanya bakteriofag melainkan ada bentuk virus yang lainnya. Hal ini juga bertujuan agar penataan unsur tata letak memiliki kesatuan dan harmonis. Penataan unsur tata letak harus memiliki kesatuan, sesuai atau harmonis, dan menampilkan kesan irama yang baik agar memperjelas fungsi atau materi pada isi buku [15]. 
Jurnal Biologi dan Pembelajarannya, Vol 5 No 2, April 2021. Pp: 19-25

e-ISSN: $2406-8659$

Modul pembelajaran yang telah divalidasi oleh ahli materi dan ahli media pembelajaran, selanjutnya direvisi dan diuji coba kepada peserta didik. Data hasil uji coba berupa respon peserta didik (Tabel 4) serta saran dan masukan dari peserta didik.

Tabel 5 Data Hasil Respon Peserta Didik

\begin{tabular}{|c|c|c|c|c|c|}
\hline \multirow{2}{*}{ No } & \multirow{2}{*}{ Pertanyaan } & \multicolumn{3}{|c|}{ Skor } & \multirow{2}{*}{ Keterangan } \\
\hline & & $\Sigma X$ & $\sum X \mathbf{i}$ & $\%$ & \\
\hline 1 & $\begin{array}{l}\text { Apakah saudara lebih memahami konsep materi } \\
\text { pembelajaran materi virus dengan menggunakan } \\
\text { modul daripada memakai media LKS? }\end{array}$ & 10 & 10 & 100 & Sangat Baik \\
\hline 2 & $\begin{array}{l}\text { Apakah penggunaan modul dapat memudahkan } \\
\text { saudara dalam pembelajaran materi virus }\end{array}$ & 10 & 10 & 100 & Sangat Baik \\
\hline 3 & Apakah modul yang disajikan menarik? & 10 & 10 & 100 & Sangat Baik \\
\hline 4 & $\begin{array}{l}\text { Apakah bahasa dan penjelasan dalam modul mudah } \\
\text { dipahami? }\end{array}$ & 8 & 10 & 100 & Baik \\
\hline 5 & $\begin{array}{l}\text { Apakah saudara merasa lebih bersemangat dalam } \\
\text { belajar dengan menggunakan modul? }\end{array}$ & 10 & 10 & 100 & Sangat Baik \\
\hline 6 & $\begin{array}{l}\text { Apakah saudara membaca uraian dalam modul dengan } \\
\text { lengkap? }\end{array}$ & 6 & 10 & 100 & Cukup Baik \\
\hline 7 & $\begin{array}{l}\text { Apakah saudara menjadi suka membaca materi } \\
\text { pelajaran jika dalam bentuk modul ? }\end{array}$ & 10 & 10 & 100 & Sangat Baik \\
\hline 8 & $\begin{array}{l}\text { Apakah gambar yang disajikan dalam modul } \\
\text { membantu dalam memahami materi ? }\end{array}$ & 10 & 10 & 100 & Sangat Baik \\
\hline 9 & $\begin{array}{l}\text { Apakah peta konsep dalam modul memudahkan } \\
\text { saudara dalam mempelajari materi? }\end{array}$ & 10 & 10 & 100 & Sangat Baik \\
\hline 10 & $\begin{array}{l}\text { Apakah latihan soal dalam modul memudahkan } \\
\text { saudara dalam memahami materi? }\end{array}$ & 9 & 10 & 100 & Sangat Baik \\
\hline & Jumlah & 93 & 100 & & \\
\hline & Rata-Rata & & & $93 \%$ & Sangat Baik \\
\hline Ketera & & & & & \\
\hline $\begin{array}{l}\sum \mathrm{X} \\
\sum \mathrm{Xi}\end{array}$ & $\begin{array}{l}=\text { Jumlah Skor Seluruh Responden } \\
=\text { Jumlah Skor Maksimal Seluruh Responden }\end{array}$ & & & & \\
\hline
\end{tabular}

Persentase rata-rata yang diberikan responden sebesar 93\% dengan kriteria sangat baik. Ada 10 butir pertanyaan, sebanyak 7 butir pertanyaan memperoleh skor 10, satu butir pertanyaan memperoleh skor 9, satu butir pertanyaan memperoleh skor 8 , dan satu butir pertanyaan memperoleh skor 6 . Adapun butir pertanyaan yang memperoleh skor terendah (6) adalah butir nomor 6 dengan pertanyaan "Apakah saudara membaca uraian modul dengan lengkap". Hal ini dikarenakan rendahnya minat baca peserta didik, sehingga pengetahuan yang diperoleh sedikit. Minat baca mempengaruhi kecenderungan seseorang untuk membaca, yang akan berperan dalam peningkatan pengetahuannya [16].

\section{SIMPULAN}

Modul pembelajaran biologi berbasis Reading, Questioning and Answering (RQA) materi virus kelas $\mathrm{X}$, yang dikembangkan melalui penelitian ini sangat layak berdasarkan hasil validasi ahli materi dan ahli media pembelajaran. Ahli materi memberikan persentase rata-rata 92,18\% dan ahli media pembelajaran memberikan persentase rata-rata 93,42\%. Modul pembelajaran biologi berbasis Reading, Questioning and Answering (RQA) materi virus kelas $X$ yang telah direvisi berdasarkan saran dari para validator, diuji keterbacaannya kepada peserta didik. Respon peserta didik memberikan persentase rata-rata 93\% dengan kriteria sangat baik. Berdasarkan hasil validasi ahli materi, ahli media pembelajaran, dan respon peserta didik maka modul pembelajaran biologi berbasis Reading, Questioning, and Answering (RQA) dinyatakan layak untuk digunakan sebagai media pembelajaran materi virus di kelas $X$. 
Jurnal Biologi dan Pembelajarannya, Vol 5 No 2, April 2021. Pp: 19-25

e-ISSN: $2406-8659$

\section{SARAN}

Saran yang dapat diajukan berdasarkan penelitian yang telah dilakukan adalah perlu dilakukan penelitian selanjutnya untuk mengetahui pengaruh modul pembelajaran berbasis RQA materi virus terhadap hasil belajar peserta didik.

\section{UCAPAN TERIMA KASIH}

Peneliti mengucapkan terima kasih kepada kedua orang tua yang selalu memberikan dukungan material, moral dan do'a, seluruh dosen yang telah memberikan bimbingan, arahan, motivasi, dan semangat, serta peneliti mengucapkan terimakasih kepada pihak MA Bahrul U'lum yang telah memberikan kesempatan kepada peneliti untuk melakukan penelitian.

\section{DAFTAR PUSTAKA}

[1] Prastowo, A. 2012. Panduan Kreatif Membuat Bahan Ajar Inovatif. Yogyakarta: Diva Press.

[2] Rohmiyati, N., Ashadi, A., \& Utomo, S. 2016. Pengembangan Modul Kimia Berbasis Inkuiri Terbimbing pada Materi Reaksi Oksidasi-Reduksi. Jurnal Inovasi Pendidikan IPA, 2 (2): 223-229, doi:http://dx.doi.org/10.21831/jipi.v2i2.4869.

[3] Corebima, 2016. Pembelajaran Biologi di Indonesia Bukan Untuk Hidup. Makalah disajikan dalam Seminar Nasional XIII Pendidikan Biologi FKIP UNS tahun 2016. Proceding Biology Education Conference, 13 (1) 8-22.

[4] Bahtiar. 2011. Potensi Pembelajaran Yang Memadukan Strategi Think Pairs Share (TPS) dan Reading Questioning Answering (RQA) untuk Meningkatkan Sikap Sosial dan Penguasaan Konsep Biologi Siswa SMA Multietnis di Ternate. (Online), https://jurnal.uns.ac.id/prosbi/article/view/6500/5880, diakses 15 Februari 2020.

[5] Aldoobie, N. 2015. ADDIE Model. (Online), http://www.aijcrnet.com/journals, diakses 23 April 2019.

[6] Riduwan. 2013. Skala Pengukuran Variabel-Variabel Penelitian. Bandung: Alfabeta.

[7] Khairunnisa, F. 2019. Evaluasi Komponen Kelayakan Isi Buku Ajar Bahasa Indonesia: Kesesuaian Materi dengan Kurikulum. Jurnal Penelitian Pendidikan Bahasa dan Sastra. 4 (1) : 408-416.

[8] Nurhasikin., Ningsih, K., \& Titin, T. 2019. Pengembangan Modul Berbasis Discovery Learning Materi Struktur dan Fungsi Jaringan Tumbuhan SMA. Online. Jurnal Informatika dan Sains. 8 (2) : 163-178.

[9] Devianty, R. 2019. Membangun Bahasa Komunikatif untuk Anak Usia Dini. Jurnal Tarbiyah UINSU., 9 (2): 113.

[10] Nurafni, A., Pujiastuti, H. \& Mutaqin, A. 2020. Pengembangan Bahan Ajar Trigonometri Berbasis Kearifan Lokal. Journal of Medives: Journal of Mathematics Education IKIP Veteran Semarang, 4 (1) : 71-80.

[11] Fahrudiin, I. 2020. Analisis Buku Ajar Sejarah Kebudayaan Islam Menurut Badan Standar Nasional Pendidikan. Tarlim Jurnal Pendidikan Agama Islam, 3 (1) : 15-25.

[12] BSNP. 2014. Instrumen Penilaian Buku Teks Pelajaran. Jakarta. Badan Standar Nasional Pendidikan.

[13] Himala, Trihanis, P, S., Ibrahim, M., \& Fitrihidajati, H. 2016. Keterbacaan Teks Buju Ajar Berbasis Aktivitas pada Materi Ruang Lingkup Biologi Kelas X SMA. Jurnal BioEdu., 5 (3): 445-448.

[14] Rahmawati, R, A., Sarwi, S., \& Darsono, T. 2019. Penyusunan Bahan Ajar IPA Fisika sebagai Upaya Peningkatan Literasi Sains Peserta Didik pada Tema Bunyi. Unnes Physics Education Journal, 8(2): 193207.

[15] Silfianah, I. 2020. Development Of Multiple Representation-Based General Chemistry Textbook Using Guided Inquiry. EduChemia (Jurnal Kimia dan Pendidikan), 5 (2): 2502-4787.

[16] Kurniawati, L. \& Mitarlis. 2020. Pengembangan Media CPB dengan Strategi Mind Mapping Materi Hidrokarbon untuk Menigkatkan Minat Baca Peserta Didik. UNESA Journal of Chemical Education., 9(3) : 379-386. 